\title{
Indigenous Traditional Knowledge on Health and Equitable Benefits of Oil Palm (Elaeis spp.)
}

\author{
Medagam Thirupathi Reddy ${ }^{1}$, Motha Kalpana ${ }^{1}$, Natarajan Sivaraj', Venkateswaran Kamala ${ }^{2}$, \\ Someswara Rao Pandravada², Neelam Sunil ${ }^{2}$
}

\author{
${ }^{1}$ Horticultural Research Station, Dr. Y.S.R. Horticultural University, Vijayarai, Andhra Pradesh, India \\ ${ }^{2}$ National Bureau of Plant Genetic Resources, Regional Station, Hyderabad, Telangana, India \\ Email: *medagamtr@yahoo.co.in
}

How to cite this paper: Reddy, M.T., Kalpana, M., Sivaraj, N., Kamala, V., Pandravada, S.R. and Sunil, N. (2019) Indigenous Traditional Knowledge on Health and Equitable Benefits of Oil Palm (Elaeis spp.). Open Access Library Journal, 6: e5103.

https://doi.org/10.4236/oalib.1105103

Received: December 10, 2018

Accepted: January 15, 2019

Published: January 18, 2019

Copyright $\odot 2019$ by author(s) and Open Access Library Inc.

This work is licensed under the Creative Commons Attribution International License (CC BY 4.0).

http://creativecommons.org/licenses/by/4.0/

\begin{abstract}
Recent international policy resolutions have recognized the importance of indigenous knowledge and potential of native medicinal plants in providing health and equitable benefits to the indigenous communities. Lack of knowledge on available native medicinal plants and their health potential may result in inappropriate health care practices causing ailments and associated problems. Oil palm is among the plants that are widely used by the traditional natives of West Africa. Every part of the oil palm has domestic, economic, environmental and medicinal values. This review aims at exploration, perpetuation and preservation of indigenous knowledge on oil palm for health and equitable benefits for incorporation of the same into primary health care system. The traditional medicinal uses of oil palm by indigenous communities are well known from the bibliographical records. The literature consulted for this review was obtained from Medline, PubMed, Embase, Science Direct, Scopus, SID and Google Scholar search carried out from October, 2018 to November, 2018. The literature survey and screening of data revealed that preparations from different parts of Elaeis guineensis are widely used in traditional medicine by the indigenous communities, with most of the uses relating to leaf, fruit, seed, infructescence/inflorescence, root and heart. E. guineensis is used in traditional medicine mostly without being mixed with other plants, and less commonly in mixtures, sometimes in mixture with products of animal origin to treat ailments like malaria, anaemia, gonorrhoea, amenorrhea, menorrhagia, hernia, rheumatism, bronchitis, hepatitis, small pox, measles, influenza, fever, dysentery, pleurisy, lumbago, cancer, asthma, diabetes, epilepsy, headache, earache, perinatal abdominal pain, hiccoughs, convulsions, filariasis, candidiasis, Tinea cruris, to reduce mental fatigue, mental disorders, palpitations and heart trouble, to regulate body temperature, to heal ulcers, boils, piles, cuts and fractures, for sexual impotence, male
\end{abstract}


and female sterility, easy flow of menses, to prevent miscarriage, to reduce bleeding during pregnancy, to promote easy delivery of women, for postpartum placental retention, to increase milk flow in nursing mothers, to encourage children to walk at an early age, to accelerate maturity and softness of boils and abscesses, to remove thorns from body and as a poison antidote. Elaeis oleifera has a narrow range of ethno-medicinal uses as it was cited to cure only stomach or gastrointestinal disorders. On the whole, all parts of $E$. guineensis have ethno-medicinal uses, and further research is required as to explore the potential therapeutic properties, clinical and toxicological aspects of this plant. The result of this study provides the basis for further pharmacological studies on the herbal remedies used.

\section{Subject Areas}

Public Health, Sociology

\section{Keywords}

Elaeis guineensis, Elaeis oleifera, Ethnic Groups, Ethno-Botany, Ethno-Medicine, Health Benefits, Indigenous Knowledge, Indigenous Medicine, Oil Palms, Perceptions

\section{Introduction}

Taxonomically, the genus Elaeis is a member of the order Arecales [1], family Palmae, subfamily Cocoideae, subtribe Elaeidinae [2] [3]. The genus Elaeis [4] consists of two main species, the common oil palm Elaeis guineensis (the African oil palm) native to Africa, and Elaeis oleifera or Elaeis melanococca (the American oil palm) indigenous to South and Central America. A third species is sometimes considered, Elaeis odora or Barcella odora, though its taxonomy has not been confirmed. The genus Elaeis is present in the tropical regions of Africa and in Central and South America [5]. The genus Elaeis has a trans-Atlantic (Africa-America) distribution, with E. oleifera from the neotropics and E. guineensis from Africa [5]. E. guineensis is the major economic species, as fruits of E. oleifera have much lower oil content and are used only locally in their natural area of distribution.

Health and disease are measures of the effectiveness with which human groups, combining cultural and biological resources, adapt to their environment [6]. The use of traditional medicine and medicinal plants in most developing countries, as a normative basis for the maintenance of good health, has been widely observed. In human society from time immemorial medicinal plants have played an important role in prevention and control of diseases. Medicinal plants continue to provide valuable therapeutic agents, both in modern and in traditional medicine [7]. At least $80 \%$ of the world's populations especially in developing countries use plant materials as their source of primary health care [8]. 
Palms "the princess of the plant Kingdom", represents one of the most important plant family with respect to human use. In local terms, food and medicine is not strictly separated, and palm products operate in many ways that cannot be isolated from the larger ensembles of elements and practices of which they are part. Oil palm has been described as "probably the most useful tree in West Africa" [9]. In Africa, palm oil has many traditional uses [10]. The oil palm is as old as creation. The use of oil palm by early humans is well known from the archaeological records. Such uses date back to at least 4000 years BP [11], and it appears that people in West Africa were actively cultivating oil palm as early as 3600 - 3200 BP [12]. Human use of oil palm may date as far back as 5000 years in West Africa; in the late 1800s, archaeologists discovered palm oil in a tomb at Abydos dating back to 3000 BCE [13]. Excitingly, both E. guineensis and E. oleifera are typically closely associated with human settlements and movement [14]. Oil palm was used medicinally before any written records surviving to modern times. Oil palm is among the plants well known for its pharmacological properties [15]. Anecdotally, a variety of medicinal uses have been ascribed to oil palm, including all parts of the plant [16] [17]. E. guineensis has medicinal and other uses [18]. Besides its domestic, economic and environmental value, every part of the oil palm is valuable for medicinal purposes [19] [20]. E. guineensis is a plant widely used by the traditional natives of oil palm growing areas, particularly West Africa [15].

Ethno-botany is defined as the traditional knowledge of indigenous communities about surrounding plant diversity and how various people make use of indigenous plants found in their localities, that is, how communities of a particular region make use of indigenous plants in the region for food, clothing, shelter, medicine and other domestic activities [21]. Native people can tell much about their local plants in the area of ethno-medicinal and cultural uses. They also know how to prepare the plant for these uses, when and how to harvest it and which parts, and also when and where it grows. This traditional knowledge of plant use has been gained by trial and error over centuries and is priceless and irreplaceable. Indigenous knowledge is extremely important to humanity. One of the vital applications of indigenous knowledge systems and practices of plants is in the human and animal health care. Recent international policy resolutions have recognised the importance of indigenous knowledge and the potential of traditional vegetables in promoting nutrition and health [22]. This invaluable knowledge is being lost by the destruction of the natural ecosystems, the acculturation and anthropogenic activities of these people [23]. It is knowledge we can in fact learn from if we stop this destruction of the ecosystem [24]. Knowledge of medicinal plants combined with spirituality continues to thrive in Africa today [25]. Some recent ethno-botanical field studies confirm that divination still plays a major role in the traditional knowledge systems, and palms are still used for this purpose just as they were many years ago [26] [27] [28]. Ethno-medicinal use of plants is one of the most successful tools used in pharmaceutical industry searching new therapeutic agents for various fields of biomedi- 
cine [29]. Palms are prominent elements in African traditional medicines [30]. There is a dire need to document, preserve, perpetuate and incorporate the traditional medicinal uses of palms in general, oil palm in particular into the primary health care system. It is said that taste all and hand the knowledge down [31]. It is, however, a challenge to find detailed information on the traditional medicinal uses of oil palm, which are an integral part of indigenous medicinal systems.

Earlier reviews on African palm ethno-medicine [30] and on ritual uses of palms in traditional medicine [32] covered some aspects of traditional medicinal uses of palms in general, including E. guineensis. Earlier other reviews on diet and health aspects [20] and on medicinal uses [33] were limited to some aspects of traditional medicinal uses of E. guineensis. In addition, a review of the health benefits of the leaf extracts of $E$. guineensis has been provided extensively [34]. However, the present review is to provide detailed and additional information on traditional medicinal uses of E. guineensis and E. oleifera. This review paper aims at the exploration, perpetuation and preservation of indigenous knowledge of the oil palm possessing medicinal properties for the benefit and further questionnaire survey. This review, therefore, is set to produce an update by exploring many of the documented traditional medicinal uses of the different plant parts and/or their products of oil palm and their implications in human health. The review, however, does not extend to the core botanical aspects of the oil palm. By analyzing ethno-medicinal studies in one database we were able to demonstrate the value of oil palm in traditional medicine, and provide recommendations for the areas that should be targeted in future ethno-botanical surveys. This ambitious and wide-ranging article attempts to compile in one place everything that is known or speculated about Elaeis in a multidisciplinary tour-de-force.

\section{Materials and Methods}

The study is concerned with the ethno-medicinal uses of oil palm in the world. Two species of Elaeis namely E. guineensis and E. oleifera were included in the present study. In this study, ethno-medicine data of different parts and products of oil palm were extracted from reliable sources of traditional medicine. In addition, published scientific reports about the ethno-medicinal uses of this herbal medicine were collected via literature search in databases such as Medline, PubMed, Embase, Science Direct, Scopus, SID and Google Scholar during October, 2018 to November, 2018. The authors carried out a meta-analysis to review and assemble existing information on the ethno-medicinal uses of Elaeis spp. based on a diverse set of case studies and ethno-botanical studies. Traditional medicinal use records were organized by each plant part used for the above two oil palm species in each publication. Traditional medicinal uses were reviewed according to palm species and categories of plant part and or their product.

\section{Results}

The results are organized following the part of oil palm used for each of the two 
species.

\subsection{Elaeis guineensis}

E. guineensis has medicinal properties [35]. E. guineensis is used as medicinal plant by Annang ethnic group of Akwa Ibom State, Nigeria [36]. Folk remedies of oil palm include treatment for cancer, headache and rheumatism [15] [37] [38]. E. guineensis is an economic plant which occurs abundantly in the area and is useful for cosmetics, entertainment or judicial plant or magico-religious plant by 6 religious communities (Ikot Ekpene, Abiakpo Ikot Essien, Abiakpo Edem Idim, Ikot Enwang, Adatak and Uruk UsoIkot), Ekpene, North-Western axis of Akwa Ibom State, Nigeria [39]. E. guineensis is used as an aphrodisiac, diuretic and liniment [15] [40]. E. guineensis is used as vermifuge in Nigeria [41]. In traditional African medicine, different parts of the plant are used as laxative, diuretic and as a poison antidote [42]. Products from oil palm are antidotes [33]. Ethno-botanical studies have uncovered cases of oil palm being used to treat tumours, pains and rheumatism [15] [40]. E. guineensis is used to control headache in Congo-Brazzaville and Democratic Republic of Congo [43]. Roots, stem bark, kernel and palm oil of E. guineensis are used for control of malaria, diarrhea, asthma, measles and mental disorder at Wildlife Park of Federal University of Technology, Akure, Nigeria [44]. E. guineensis is used to control boils in Akwa Ibom State of Nigeria [36]. E. guineensis is used for the treatment of convulsions [45]. E. guineensis is documented for the first time for its use in the treatment of malaria in the Dangme West District of Ghana [46]. E. guineensis has wound healing and antibacterial activity [47]. E. guineensis has been mentioned for wound healing properties in Ghana [48]. Leaves, bark, fruits and palm oil of E. guineensis are used to heal wounds. E. guineensis is used orally in Togo to treat epilepsy [49]. E. guineensis is used in treating stomach disorders [50]. In traditional African medicine, different parts of the plant are used as a cure for gonorrhoea, menorrhagia, rheumatism, bronchitis, headache and to promote healing of fresh wounds and treat skin infections [42]. E. guineensis is the main ingredient in the recipes for the treatment of female infertility in South-western Nigeria [51]. Products from oil palm are used in the treatment of many ailments especially gastrointestinal disorders and poisons in many parts of Nigeria [33]. E. guineensis is used for control of malaria [52]. Ethno-medicinal value of $E$. guineensis is for treating malaria in western zone of Ekiti State, Nigeria [52]. E. guineensis is used for treating lumbago and malaria in Cameroon [43].

\subsubsection{Roots}

The roots of African oil palm are analgesic and are used to control headache. Root decoction treats headache, rheumatism and intestinal pain [9] [53]. Root ashes are used as post-birth aid [9] [53]. In Nigeria, root decoction is used for headache [33]. Roots are aphrodisiac and are used for the treatment of piles. Decoction of root or burnt powder of root is taken orally to treat epilepsy. In Equatorial West Africa, roots are used as diuretic. Decocted roots are ingested to 
treat malaria in Ghana [46]. Root powder mixed with kernel oil is used internally till recovery to control syphilis by Ibibio ethnic group, Akwa Ibom State, Nigeria [54]. The pulverized roots are added to drinks to cure gonorrhoea, menorrhagia and bronchitis [15]. The roots of E. guineensis are used for the treatment of skin infection, gonorrhoea, menorrhagia and bronchitis [55] [56]. Root decoction of E. guineensis is used for the preparation of herbal remedies for the treatment of malaria in the Dangme West District of Ghana [46]. Roots of E. guineensis are used for sexual impotence/aphrodisiac and for infertility in males for reproductive health care by the inhabitants surrounding the Bia Conservation area in the western region of Ghana [57]. Decoction of root is boiled and drunk for the treatment of malaria in the Dangme West District of Ghana [46].

\subsubsection{Fronds}

Leaf extract of Elaeis guineensis is an effective antioxidant comparable to vitamin C [58] [59]. Yellow leaves are used in the treatment of anaemia and fever. Leaves are also used to remove poison and thorns from the body. Leaf sap is used in preparations against skin affections. Leaves are taken to promote easy delivery in women. The leaf extract and juice from young petioles are used as application to fresh wounds. Decoction from young palm leaf is drunk for treatment of gonorrhoea in Nigeria [60]. The juice from young petioles is used to treat cuts in Gabon [61]. In traditional medicine, the leaf of E. guineensis is squeezed and the juice that is obtained is placed on wounds to promote healing [15]. A drink prepared from powdered leaves is applied as a haemostatic in Benin [62]. Decoction from the leaf is administrated orally to treat liver diseases in Morocco [63]. Dried leaves of E. guineensis are used as haemostatic in Edo State, Nigeria [64]. Powdered leaves of E. guineensis are used to heal chronic wounds in Bosomtwi-Atwima-Kwanwonwa District, Ghana [65]. Fronds of E. guineensis are used for postpartum-placental retention by the inhabitants surrounding the Bia Conservation Area in the western region of Ghana [57]. Leaves of E. guineensis are ground and applied to wounds to arrest bleeding [48]. Young leaves of E. guineensis are used as anti-aging by Yoruba folk in Ondo State, Nigeria [66]. Juice extract of the leaves is put on wounds to advance healing [40] [58]. The leaves of oil palm are used for the treatment of skin infection, gonorrhoea, menorrhagia and bronchitis [55] [56]. The juice squeezed from oil palm leaves can be applied on wounds to enhance healing while the sap is used as laxative, and in fermented form is effective for improving lactation in nursing mothers [56]. Leaf extract is also useful in treating diabetes [67]. Dropping infusion of young leaf of E. guineensis on affected part of body is useful for ear-ache of Idoma people, Benue State, Nigeria [50]. Leaves of E. guineensis are pound and mixed with palm wine in a mortar, the juice is squeezed and applied to the body to treat convulsion by the Otuo tribe in Owan East local government area, Edo State, Nigeria [68]. Leaves of E. guineensis are pound and mixed with palm wine, taken a cup thrice daily to treat dysentery by the Otuo tribe in Owan East Local Government Area, Edo State, Nigeria [68]. In E. guineensis, leaves are insecti- 
cidal [69] [70]. Decoction of fresh leaves of E. guineensis associated with Annona, Persea, Capsicum and Elaeis is consumed orally as anti-malarial in Andom village, Eastern region, East Cameroon [71]. Fresh leaves of E. guineensis associated with Ageratum conyzoides are ground and rub on child as anti-malarial in Andom village, Eastern region, East Cameroon [71]. Grinding and adding leaves of E. guineensis to wounds arrest bleeding [72].

\subsubsection{Bark}

Bark of E. guineensis plants is used for the management of cancer by traditional healers in Ogun State, Nigeria [52]. Rapure from stem bark of E. guineensis associated with Tetrapleura tetraptera is massaged on body as anti-malarial in Andom village, Eastern region, East Cameroon [71].

\subsubsection{Inflorescences/Infructescences}

Empty infructescences of E. guineensis alone or mixed with ginger (Zingiber officinale) are burnt and applied as magical medicine in the form of an enema to small children to encourage them to walk at an early age in Ghana. E. guineensis was one of the most cited species recorded in a survey and has been reported in Africa as reducing mosquito biting activity when used as repellent [73]. Dry infructescences of E. guineensis are either individually or with fresh leaves of $C$. odorata are burnt and smokes are administered to repel insects in six local communities in Cameroon [74].

\subsubsection{Palm Sap and Palm Wine}

Palm sap is extracted from E. guineensis by cutting the inflorescence and collecting the sap from the injured peduncle or inserting a tube into the palms growing point in the heart of the crown. The oil palm sap/wine is the exudates that flow when the palm is tapped [75]. The exudates (palm wine) from the palm have health significances [20]. Palm wine is a sweet, effervescent drink obtained from the fermented sap of the tropical palm tree (E. guineensis) and raphia palm trees (Raphia sp.) [76]. Palm wine of E. guineensis associated with Coffea is consumed orally as anti-malarial in Andom village, Eastern region, East Cameroon [71]. Palm wine is used in ethno-medicine as prophylactic against malaria and also used (mainly that of E. guineensis) to increase milk flow in postpartum mothers. In the native range of West Africa and less often where introduced, palm wine is produced from extracted sap from male E. guineensis flowers, and it is an important product for local use, trade and customs, and is an important source of vitamin B complex, and is worth twice the value of the oil to local people from a single tree [38]. In Equatorial West Africa, fresh sap was used as laxative. The sap has medicinal role in the cure of malaria, measles, jaundice and the flow of breast milk in nursing mothers [77]. The fresh sap from the palm tree is utilized as a laxative, and partially-fermented palm wine is administered to nursing mothers to enhance lactation [55] [78]. The sap of this plant is also used as a laxative and the partially fermented palm wine is administered to nursing mothers to improve lactation [56]. The sap has also been recorded to be involved 
in malaria, jaundice and measles treatment. The sap contains numerous phytonutrients which play significant role in human health [79].

\subsubsection{Fruits}

In Cameroon, fresh nuts of $E$. guineensis are pound or smash is mixed together with leaves from Hibiscus surattensis, Asystasia gangetica, Musa sapientum and Cyperus articulates and the mixture is rubbed on the body of the patient to reduce mental fatigue [26]. Fruit decoction of E. guineensis is taken orally as a purgative, laxative and as digestive to cure stomach ache, ulcers, etc. by the Miskitu group of Eastern Nicaragua [18]. Fruits of E. guineensis are used for treating anaemia and malignant tumours [69] [70]. Fruits of E. guineensis are used for controlling bleeding during pregnancy, miscarriage, postpartum-placental retention and lactation failure by the inhabitants surrounding the Bia Conservation area in the western region of Ghana [57]. The fruit husk of oil palm is used for the treatment of skin infections, gonorrhoea, menorrhagia and bronchitis [55] [56]. Ash from fruit husk of E. guineensis is utilised for the preparation of medicinal soaps used for treating skin infections [56]. Fruits of $E$. guineensis are used as medicinal plant by the traditional medical healers in the villages of Beregadougou and Fabedougou, Cascades Region, Burkina Faso [80]. Drinking of fruit infusion of E. guineensis is useful as anti-convulsion to Idoma people, Benue State, Nigeria [50]. Fruits of E. guineensis are reported to accelerate maturity and softness of abscesses and boils [81]. Fruits of E. guineensis are commonly used for ceremonial activities for sound health or healing and divination among the Yoruba tribe, South West Nigeria [82]. Pod and shaft of Theobroma cacao and E. guineensis are burnt both together, pour inside water and used to bathe children suffering from skin infections in Ogun State, Nigeria [83]. Juice extracted as oil from nuts of E. guineensis is used as body cream in folklore phytocosmetics of Oyo, Ogun, Ekiti, and Lagos States in Southwest Nigeria, Nigeria [84]. Fruit juice extracted as oil of E. guineensis is used as body cream [84]. Leaves of Baphia nitida, fruits of Capsicum annum, and pulp of E. guineensis are cooked and prepared with soup and is taken once a day until there is improvement for amenorrhoea [85]. Leaves of Croton zambesicus, fruits of Piper guineense, pulp of $E$. quineensis and a whole electric fish are burnt, put the ash into palm oil and rub this on the whole body at night for infertility [85]. Palm fruit pericarp of E. guineensis is peeled and used externally to control boils [43]. Nuts of E. guineensis are used for easy flow of menses in Enugu State of Nigeria [21].

\subsubsection{Palm 0il}

Palm oil is emollient and is a common excipient for herbal ointments. Palm oil is used to treat suppurations, whitlows and swellings of the legs caused by erysipelas and infestations by Filaria. Palm oil is used as a liniment for indolent tumours. Palm oil is reported to be anodyne, antidotal, aphrodisiac, diuretic and vulnerary [37]. Palm oil is used as a liniment for rheumatism. A poultice made from oil which is applied to wounds by the Bubis of the Island of Fernando Po. 
In Rwanda, a spoonful of palm oil is heated and applied on the tongue and gums to treat candidiasis in children [86]. To awake a patient in coma, red palm oil is mixed with a burned knot of the parasite Loranthus micranthus and rubbed on the patient's cheeks towards the mouth in order to make him talk [87]. For the treatment of malaria, the Yoruba used to start the ritual with two rings painted on the neck, one with shea butter (Vitellaria paradoxa), and another with $E$. guineensis oil [88]. In Nigeria, to prevent miscarriage Yoruba people used to roast a tortoise with coconut water and half a bottle of palm oil from E. guineensis, after which the mixture is ground to powder. The powder is consumed in a corn flour pudding, taken every morning and evening during one menstrual period, followed by sexual intercourse five days after finishing menstruation [88]. In Gabon, the Masango used the leaves of Hyptis lanceolata mixed with palm oil to apply on the body as medico-magic [89]. Historically, palm oil has been used for soap production [90]. Palm oil of E. guineensis in association with Myrianthus administered through oral voice to control hernia by Baka pygmies in the Dja Biosphere Reserve, Cameroon [43]. Palm oil is applied to wounds as a vulnerary in Guinea. Palm oil is administered as poison antidote and used externally as lotions with addition of other herbs for skin diseases [55] [56]. In Africa, palm oil has many traditional medicinal uses [10]. Palm oil is useful for pharmaceutical preparations [20]. In Liberia, the Mano ethnic group used red palm oil in treatments of mysterious diseases. Palm oil of E. guineensis associated with Tetrapleura is massaged as anti-malarial in Andom village, Eastern region, East Cameroon [71]. Crude red palm oil processed from palm fruit mesocarp, is administered as an antidote to poison and used with other herbs in the treatment of skin ailments [91]. Palm oil is used in the treatment of female infertility in south-western Nigeria [92]. Documented uses of palm oil include treating prostate diseases, use as a component in skin lotion, and as a carrier for medicinal extracts of other plants [93]. Mesocarp oil is used in various medicines and ointments [9] [94] [95] [96].

In Liberia, Mano ethnic group bend a stick from each of the following trees or shrubs namely Ricinodendron africanum, Dracena sp., Whitfieldia lateritia and any small twig broken over with the break healed so that the stick is growing in the twisted or bent position and calcined. The calcined wood is powdered and mixed with the red palm oil, the ointment is rubbed on the area over the fracture to heal fractures [87]. A whole vine of Clerodendron sp. is calcined and beaten to powder, which is kept in a small horn, and a small amount is mixed with red palm oil and eaten to relieve from hiccough by Mano ethnic group in Liberia [87]. An inflorescence of Costus sp. is peeled to which a handful of buds of $\mathrm{Ha}$ rungana madagascariensis is added and all beaten up in a mortar. Some of the mixture is put in an iron spoon with red palm oil; four pebbles are heated in the fire (three if for a woman), dropped into the spoon and the patient licks the spoon to reduce palpitation by Mano ethnic group in Liberia [87]. A young shoot of unidentified plant is beaten up to a pulp and put in the spoon with a little palm oil and three (or four) pebbles are heated in the fire and added to the 
spoon, stirred until cool down in the morning before the patient has eaten. The patient takes the contents of the spoon into his mouth spitting out the stones far away and swallowing the pulp. What is left on the spoon is rubbed over the pericardium to reduce heart trouble and rapid pulse of Mano ethnic group in Liberia [87]. A small horn is filled with powdered charcoal from various plants mixed with red palm oil and leaves beaten to pulp and rubbed on joints to reduce rheumatism due to yaws of Mano ethnic group in Liberia [87]. A handful of Biden spilosa was burnt to ashes and ashes were mixed with palm oil and the doctor rubs the ointment on his hands, make two false passes around the patient's chest from back to front, then with the third he rubs hard will relieve respiratory pain due to pleurisy by Mano ethnic group in Liberia [87]. A handful of thorns of Combretum grandiflorum is burned to charcoal in a pot and then heated with red palm oil and the ointment was used to anoint the ankles, knees, and elbows to relieve from influenza of Mano ethnic group in Liberia [87]. A piece of a large shelf fungus shaped like a liver is charred, powdered and mixed with palm oil and the ointment is rubbed over the liver to control acute hepatitis of Mano ethnic group in Liberia [87]. A knot of the parasite Loranthus micranthus where it joins the host branch is calcined and triturated in an iron pot. The black powder is mixed with red palm oil, rubbed on the patient's cheeks towards the mouth and he will talk to come out of coma by Mano ethnic group in Liberia [87].

Three seeds of Ricinodendron heudelotii subsp. africanum (Ricinodendron africanum) and a quantity of blooms of Canna indica (Canna bidentata) are beaten together in a mortar, and put into a big spoon. Then a little salt and red palm oil (freshly prepared, not refined by heating) is added. Three pebbles are put in the fire and allowed to get hot, then one of these "rocks" is put into the spoon and stirred until it has cooled, and then discarded. The same process is repeated with two other rocks and the product is consumed orally to cure amenorrhea of Mano ethnic group in Liberia [87]. Bark fibers of Waltheria americana are twisted into a cord to be worn around the waist. The cord and loin cloth are smeared with an ointment made of the flower stalks of Cyathula prostrate, fried black, and ground up with palm oil and worn around the waist to cure gonorrhea by Mano ethnic group in Liberia [87]. Ointment made of some plant (name unclear) and charred big black ants-ground with palm oil used to cure Tinea cruris by Mano ethnic group in Liberia [87]. Leaves of Combretum aculeatum growing on dry ground are fried in palm oil along with a finger ring of the patient in the pot the mass is rubbed on the legs and the ring is worn to cure chronic ulcers by Mano ethnic group in Liberia [87]. A piece of every sort of thorny shrub or scratchy vine is collected and all calcined in a pot, beaten to a black powder in a mortar and mixed with red palm oil. The medicine is put into a horn or into a big acatma snail shell. Only the horn of the black antelope ( $\mathrm{Ce}$ phalopus niger) is a taboo for this purpose. Leaves of Mareya spicata are beaten up with clay and a little put in the horn before it is filled with a calcined mixture. A little is eaten and rubbed on the wound is thought to be efficient first-aid 
treatment to snake bites by Mano/BaKona ethnic group in Liberia [87]. Calcined twig of Protomegabariastapfiana (Protomegabariastaphiana) mixed with red palm oil and salt and put into a horn. She may lick the medicine from the end of the finger if she feels dizzy or afraid as protection for women and getting sick as a result of her contact with the snake people when she attends a meeting to sing and dance by Mano/BaKona ethnic group in Liberia [87]. Leaves of Kalanchoe sp., leaves of Peperomia pellucid and powdered snail shells are mixed into an oily base consisting of palm oil and shea butter. Preparation of the ointment is accompanied by the long incantation. A particular Ifa sign should be made upon the surface of the calabash containing the ingredients the resulting ointment is efficacious in reducing pock marks or scarring against smallpox by Yoruba ethnic group in Nigeria [88]. A bark of a tree from Rutaceae family is mixed with young branches of Mimosa sp. and Byrsocarpus coccineus, thoroughly roasted in a pot, beaten to powder and mixed with red palm oil and crocodile gall, kept in a horn of the black antelope. A little of a poison is put under the thumb-nail and placed in the palm wine and used as a black magic poison by Mano ethnic group in Liberia [87].

\subsubsection{Kernels}

The herbal preparation is made of a boiling water extract from a powdered sample containing Alstonia boonei root bark (90\%), Rauvolfia vomitoria root bark (5\%), and E. guineensis nut without pericarp (5\%) was found to be of anti-inflammatory activity [97]. In Cameroon, palm kernels are grilled to produce black oil called magnanga, famous for its numerous medicinal uses [98]. In Cameroon, fresh seeds of $E$. guineensis were mashed and mixed with other plants to treat mental fatigue. Seeds of E. guineensis are used for miscarriage in Bia Biosphere Reserve in the western region of Ghana [57]. Kernels of E. guineensis is used for sexual impotence/aphrodisiac, infertility in males, controlling bleeding during pregnancy, miscarriage, postpartum-placental retention and lactation failure by the inhabitants surrounding the Bia Conservation area in the western region of Ghana [57]. Kernels of E. guineensis are used as hair lotion, antipoison and anticonvulsion by Igala people of Kogi State, Nigeria [99].

\subsubsection{Palm Kernel 0il}

Palm kernel oil was used in various antidotes, medicinal ointments and enemas [9] [94] [95] [96] [100]. Crude palm kernel oil is used to regulate body temperature of convulsive children. In Liberia, palm kernel oil was applied with owl's feathers on wounds resulting from scarification performed during the Poro initiation rites [87]. Palm kernel oil was recognized as health oil in Ayurvedic medicine almost 4000 years ago [101] [102]. Baka pygmies in the Dja Biosphere Reserve, Cameroon use seed oil of E. guineensis in association with Alchornea through scarification for curing lumbago [43]. Palm kernel oil of E. guineensis in association with either Alchornea or Celtis or Haumania or Pentaclethra or Polyalthia or Scleria is administered through scarification to control headache by Baka pygmies in the Dja Biosphere Reserve, Cameroon [43]. Palm kernel oil of 
E. guineensis in association with Raphia is administered through onction to control scabies by Baka pygmies in the Dja Biosphere Reserve, Cameroon [43]. Palm kernel oil of E. guineensis in association with either Piptadeniastrum or Polyalthia is administered through scarification to control malaria by Baka pygmies in the Dja Biosphere Reserve, Cameroon [43]. Palm kernel oil of E. guineensis in association with either Alchornea or Funtumia or Hua or Penda or Terminalia is administered through scarification to control Lumbago by Baka pygmies in the Dja Biosphere Reserve, Cameroon [43]. Palm kernel oil is administered as poison antidote and used externally as lotion with addition of other herbs for skin diseases [55] [56]. Seed oil of E. guineensis associated with Ageratum was rub on child as anti-malarial in Andom village, Eastern region, East Cameroon [71]. Palm kernel oil is used as a compliment to other medicinal plant extracts by making it palatable and consumed orally to treat skin diseases, stomach disorders and convulsion in children [81]. Robbing seed oil of E. guineensis with Scleria boivinii on the infected part of body was useful for headache of Idoma people, Benue State, Nigeria [50].

\subsubsection{Palm Heart (Palm Cabbage)}

Preparations made from the palm heart are used to treat gonorrhoea, menorrhagia, and perinatal abdominal pain, and are considered laxative, anti-emetic and diuretic. Decoction from palm heart was drunk in Nigeria for treatment of gonorrhoea [60]. Medicine prepared from palm "cabbage" was used to treat menorrhagia, abdominal pain, gonorrhoea and bronchitis [53].

\subsection{Elaeis oleifera}

Mesocarp oil is extracted for cooking and other uses [103]. E. oleifera has food, medicinal and other uses for Miskitu group of eastern Nicaragua [18]. Fruit decoction of $E$. oleifera is taken orally as a purgative, laxative and as digestive to cure stomach ache, ulcers, etc. by the Miskitu group of eastern Nicaragua [18].

\section{Discussion}

Vast information is available on ethno-medicinal uses of E. quineensis across the African and American continents in several references, published between 1937 [60] [104] and till date [52] [68] [74]. On contrary, scanty information is found on ethno-medicinal uses of E. oleifera across the American continent in only one reference published in 1997 [18]. Although there were several studies on ethno-medicinal uses of E. guineensis in Africa: East Africa (Rwanda), West Africa (Togo, Liberia, Guinea, Benin, Nigeria, Ghana, Islans of Fernando Po and Burkina Faso), Central Africa (Cameroon and Gabon), North Africa (Moracco) and East and Central Africa (Democratic Republic of Congo), there was only one study on ethno-medicinal uses of E. guineensis and E. oleifera in America: Central America (Nicaragua) [18]. It indicates that E. guineensis is probably the most useful oil palm species in West Africa, while E. oleifera the most useful oil palm species in Central America. 
We found references to ethno-medicinal uses of E. guineensis in sub-Saharan Africa [26] [46] [60] [62] [63] [65] [73] [74] [86] [87] [88] [89] [98], and they were used for different purposes. Based on the published information, the ethno-medicinal usefulness of $E$. guineensis in African continent is remarkably high. E. guineensis is native to tropical Africa, from Sierra Leone in the west through the Democratic Republic of Congo in the east. It is native to west and southwest Africa, specifically the area between Angola and The Gambia; the species name guineensis refers to the name for the area, Guinea, and not the modern country which now bears that name. It is generally agreed that the E. guineensis is originated from the equatorial tropical rain forest region of Africa, precisely along the gulf of Guinea. It was domesticated in its native range, probably in Nigeria, and moved throughout tropical Africa by humans who practiced shifting agriculture at least 5000 years ago. European explorers discovered the oil palm tree in the late 1400 's, and distributed it throughout. The species is also now naturalised in Madagascar, Sri Lanka, Malaysia, Indonesia, Central America, the West Indies and several islands in the Indian and Pacific Oceans. E. guineensis exists in the wild type and cultivated state. E. guineensis is cultivated in humid tropical regions of Africa, Central and South America and Asia. E. guineensis is present in Africa (Angola, Benin, Burundi, Cameroon, Central African Republic, Congo, Congo Democratic Republic, Côte d'Ivoire, Equatorial Guinea, Gabon, Gambia, Ghana, Guinea, Guinea-Bissau, Kenya, Liberia, Madagascar, Malawi, Mauritius, Nigeria, Reunion, Sao Tome and Principe, Senegal, Sierra Leone, Sudan, Tanzania, Togo, Uganda and Zimbabwe [38] [105] [106] [107]; Central America (Caribbean, Costa Rica, Dominican Republic, Guatemala, Honduras, Martinique, Nicaragua and Panama) [105] [107] [108], South America (Bolivia, Brazil (Amazonas, Bahia and Para), Colombia, Ecuador (Galapagos Islands), Paraguay, Peru, Suriname and Venezuela [105] [107] [108] [109], North America (Mexico and USA (Florida and Hawaii)) [108] [109] [110], Oceania (Cook Islands, Fiji, French Polynesia, Guam, Marshall Islands, Micronesia, Federated states of New Caledonia, Niue, Palau, Papua New Guinea and Solomon Islands) and it is of introduced origin and non-invasive [107] [109] and Asia (Cambodia, China, Christmas Island (Indian Ocean), India (Andaman and Nicobar Islands, Andhra Pradesh and Kerala), Indonesia (Java and Sumatra), Malaysia (Peninsular Malaysia, Sabah and Sarawak), Myanmar, Philippines, Sri Lanka, Thailand and Vietnam [105] [107] [108] [109]. Our expectation that E. guineensis would be used extensively in traditional medicine and far more than on the African continent was not confirmed by our survey of the relevant literature.

There is currently only one document on E. oleifera ethno-medicinal properties [18]. Since our literature search was rather intensive we conclude that there are no ethno-botanical studies focusing on the ethno-medicinal usefulness of $E$. oleifera distributed in Central America, Northern South America, Brazil, Colombia and Madagascar. E. oleifera is native to tropical Central America and South America. The main belt runs through the southern latitudes of Cameroon, 
Côte d'Ivoire, Ghana, Liberia, Nigeria, Sierra Leone, Togo and into the equatorial region of Angola and the Congo. However, traditional medicinal uses of this species were not reported from any one of these countries. No ethno-botanical uses have been formally reported from Ecuadorean populations of $E$. oleifera. In Ecuador, the only indigenous name reported in the literature comes from the Achuar communities, where it is known as Yunchik [111]. However, there is a limited amount of information from other countries about traditional uses, which include folk remedies, beverages, insect repellents and cooking [14]. There are many parts of the world yet to be explored for ethno-medicinal uses of E. quineensis and E. oleifera. Further studies and collecting trips may generate a more complete picture and suggest answers to why (or if) there are few traditional medicinal uses of E. oleifera compared to other common species $E$. quineensis. Future ethno-botanical surveys should be directed at the central African region, because palm species richness (and plant species richness in general) is particularly high in this area, and only few ethno-botanical studies available have focused on this region.

The importance of E. guineensis crop is due to their medicinal properties and utilization as food [35]. The review of literature revealed that both oil palm species of the genus Elaeis under study were found to be involved in various traditional medicinal practices in African and American continents. E. quineensis has a wide range of ethno-medicinal uses as it was cited to treat ailments like malaria, anaemia, gonorrhoea, amenorrhea, menorrhagia, hernia, rheumatism, bronchitis, hepatitis, small pox, measles, influenza, fever, dysentery, pleurisy, lumbago, cancer, asthma, diabetes, epilepsy, headache, earache, perinatal abdominal pain, hiccoughs, convulsions, filariasis, candidiasis, Tinea cruris. Further, it was cited to reduce mental fatigue and mental disorders, to reduce palpitations and heart trouble, to regulate body temperature, to heal ulcers, boils, piles, cuts and fractures, for sexual impotence, male and female sterility, easy flow of menses, miscarriage, to reduce bleeding during pregnancy, to promote easy delivery of women, for postpartum placental retention, to increase milk flow in nursing mothers, to encourage children to walk at an early age, to accelerate maturity and softness of boils and abscesses, to remove thorns from body and a poison antidote. E. oleifera has a narrow range of ethno-medicinal uses as it was cited to cure only stomach or gastrointestinal disorders (e.g. stomach ache, ulcers, etc.). The data revealed that while E. guineensis was found relevant in several use categories, E. oleifera was found relevant in few use categories. With 258 medicinal use records for different use categories (infections/infestations, digestive system disorders, genito-urinary system disorders, ritual/magical uses, respiratory system disorders, pain, inflammation, skin/subcutaneous cellular tissue disorders, injuries, pregnancy/birth/puerperium disorders, muscular-skeletal system disorders, circulatory system disorders, endocrine system disorders, poisonings, veterinary medicine, nervous system disorders, nutritional disorders, blood system disorders, cultural diseases and disorders, mental disorders, ab- 
normalities and defined symptoms), E. guineensis tops the list of palms used in traditional medicine in Africa [112]. It means that among numerous palms used in African traditional medicine, E. quineensis has been widely used in the traditional medicine due to its edibility. Further, ostentatious that palm oil or red palm oil always comes from E. guineensis, this was the most commonly documented palm species for medicinal purposes in Africa. Our review shows that $E$. guineensis has been, and probably still are pervasive in African medicinal systems. Its use in medicines reflects the spiritual framework of traditional medical practices, and African oil palms themselves are important and often crucial in disease treatment and prevention. Since E. guineensis is mainly found in the home gardens [35], it is commonly used in African traditional medicine as a household remedy. The documented ethno-medicinal uses may be attributed to the presence of a high concentration of minerals and various other phytochemicals of diverse chemical structure. However, there is no assurance that E. guineensis used for the treatment of a particular disease has any biologically active component; it may only be its symbolic or spiritual meaning that serves as a powerful ingredient. The results of this study provide the basis for further pharmacological studies on the herbal remedies used. The present study concluded that further clinical and phytochemical experimentation is needed.

The data on the medical use of traditional preparations from all parts of $E$. guineensis display a wide spectrum of applications in African and American continents. E. guineensis and E. oleifera were cited as being used for treatment of more than a disease. This confirms the multi-curative ability of medicinal plants, in general, oil palm in particular. The review also revealed that the indigenous people have administering preparations made from bark, roots, leaves, infructescence/inflorescence, fruits and seeds of Elaeis. While only fruits of $E$. oleifera were used in traditional medicines, all parts of the E. guineensis were used in traditional medicines. However, the most commonly used part was the leaf, followed by the fruit, seed, root, inflorescence/infructescence. The ethno-medicinal uses of all the mentioned parts were found in both older and recent literature, although most of the recent medicinal use records were associated with the palm leaf. Every part of E. guineensis has been of use in the various traditional and folk systems of medicines where E. guineensis palms are found to be indigenously growing. All plant products of the E. guineensis were used in traditional medicines. However, the most commonly used part was the palm oil extracted from the mesocarp of fruits, followed by the palm kernel oil extracted from the seed, plant sap extracted from the palm heart and palm wine. Each part of the oil palm tree has some medicinal property and is thus commercially exploitable.

Analysis of data revealed that some of the plant parts and crude products of $E$. guineensis were used in traditional medicine purely, while other plant parts and crude products were used in traditional medicine mostly without being mixed with other plants, and less commonly in mixtures, sometimes in mixture with 
products of animal origin (e.g. tortoise, giant black ant, electric fish, crocodile, snail, shea butter, etc.). It means that in some treatments, the oil palm is the central element of traditional medicines. In other cases, oil palm is used in mixtures with other plants and or animals or products. Hence, oil palms are not the primary ingredient, but support the medicinal treatments in some way, like in the case of palm oil, used as a medium to blend and make coherent the various ingredients. It is noteworthy that palm wine and palm oil, which are commonly consumed in Africa, often assist the treatment and the contact with the supernatural world. Because several traditional medicinal uses of E. guineensis listed in the literature could not be unequivocally referred to a particular species, the picture we draw remains somewhat incomplete with regards to the taxonomic basis for ethno-medicinal uses.

Ethno-medicinal uses of $E$. quineensis were documented for 17 different ethnic groups in 5 different countries in Africa and one country in America. The analysis of data revealed that the dominant ethnic groups associated with the usage of different parts of African oil palm in traditional medicine were Mano/Idoma in Liberia [71] [87], Yoruba in Nigeria [66] [82] [88], Idoma in Nigeria [50], Otuo in Nigeria [68], Ikot Ekpene, Abiakpo Ikot Essien, Abiakpo Edem Idim, Ikot Enwang, Adatak and Uruk Usolkot in Nigeria [39], Annang in Nigeria [36], Ibibio in Nigeria [54], Igala in Nigeria [99], Miskitu in Nikaragua [18]), Bubis in the Island of Fernando Po (Personal communication), Masango in Gabon [89] and Baka in Cameroon [43]. On contrary, ethno-medicinal uses of $E$. oleifera were documented for only one ethnic group Miskitu in only one country Nikaragua in Central America [18]. The review also revealed that over many years, these local communities in Africa and America have acquired valuable practical knowledge on the traditional medicinal uses of oil palm and therefore to some extent actively manage their health guided by indigenous knowledge. It is imperative that this knowledge, which is mostly passed by word of mouth from generation to generation, should be adequately documented for referral purposes. Furthermore, the active participation of such natural custodians and practitioners of valuable knowledge is guaranteed in bioactive principles and the development of new drugs. There is a need to build on the existing resources of indigenous landraces of Elaeis species by improving on their management to sustain the plant genetic resources as well as further domestication of highly valued indigenous landraces of Elaeis species. Focus is to be given to indigenous/ tribal/ ethnic/ minorities in these countries with contributions to definitions of these groups, the extent of their diversity, and the importance of their traditional medicinal knowledge of local oil palm resources. The few studies we reviewed that explained the medicinal uses of oil palms in detail were classic anthropological works that embraced studies of the entire native African tribes and cultures [43] [50] [87]. The best accounts of traditional medical practices came from those who spent years among the local people, not only observing but also sharing their everyday life. Many of the oil palm uses mentioned in our review came from these sources, but in many cases we do not know whether the cited medi- 
cinal uses are still practiced today, as recent studies on African medicinal plants are scarce.

\section{Conclusions}

In this systematic review, the ethno-botanical studies conducted on oil palm (Elaeis spp.) indicate that of the two species of Elaeis under study, E. guineensis has been used extensively in local treatment of various ailments, while few ethno-medicinal uses of E. oleifera have been documented. Every part of E. guineensis has been of use in various traditional and folk systems of medicines where E. guineensis is found to be growing. Virtually all the different parts and products of the E. guineensis plant have one or more ethno-medicinal uses and have been used for different purposes in various parts of the African and American continents. According to the results of this study, all parts of E. quineensis have health and equitable benefits, in general, and have immense potential in the treatment of gonorrhoea, menorrhagia, and bronchitis, headache, rheumatism, to promote healing of fresh wounds and treat skin infections. The data revealed that $E$. guineensis is conspicuous in traditional medicines in Africa contributing to healthcare of rural dwellers. Properly studied and recorded, this traditional knowledge could revolutionize the world of medicine.

Based on literature survey and screening, it can be deduced that although $E$. quineensis is traditionally used in the treatment of various diseases for long time, no preliminary screening on the chemical composition, potential therapeutic properties, clinical and toxicological aspects of different plant parts and products has been carried out. Hence, researchers may have to focus on understanding of the total composition of different plant parts and products of oil palm to explore its potential in indigenous health care system. Further research is also required to explore therapeutic properties, clinical and toxicological aspects of this plant. Considering the significance of African oil palm in the field of ethno-medicinal science, work must be carried out to exploit the therapeutic utility of this plant to combat diseases. Attention must be given on the development of modern drugs after thorough investigations on the bioactivity, mechanism of action, pharmacotherapeutics, toxicity and similar aspects of chemical constituents of African oil palm extracts. There is still a lot of scope in this field for better utilization of this wonder plant. As the global scenario is now changing towards the use of nontoxic plant products having traditional medicinal use, development of modem drugs from oil palm should be emphasized for control of various diseases. In fact, time has come to make good use of centuries-old knowledge on oil palm through modern approaches of drug development.

The review also revealed that over many years, several local communities in Africa have acquired valuable practical knowledge on the traditional medicinal uses of oil palm and therefore to some extent actively manage their health guided by indigenous knowledge. There is an urgent need for agricultural research centres, national agricultural research systems, universities, and commu- 
nity-based organizations to work together under a shared policy framework with the aim of developing a strong evidence based health care linking traditional knowledge and modern medicine. A comprehensive proactive policy framework is the best way to conserve indigenous knowledge and incorporate the same into the primary health care system.

There are many parts of the world yet to be explored for ethno-medicinal uses of $E$. quineensis and E. oleifera. Further studies and collecting trips may generate a more complete picture and suggest answers to why (or if) there are few traditional medicinal uses of E. oleifera compared to other common species E. quineensis. Future ethno-botanical surveys should be directed at the central African region, because palm species richness (and plant species richness in general) is particularly high in this area, and only few ethno-botanical studies have focused in this region. A better understanding of the cultural context of medicinal use of oil palm species is needed in order to obtain a more accurate and complete insight into palm-based traditional medicines. Effort must be made to provide meticulous reports on traditional remedies, as the enduring value of African medicines lies not only in the materials used, but also in the methods and the concepts underlying them.

\section{Conflicts of Interest}

The authors declare no conflicts of interest regarding the publication of this paper.

\section{References}

[1] Cronquist, A. (1981) An Integrated System of Classification of Flowering Plants. Columbia University Press, New York.

[2] Dransfield, J., Uhl, N., Asmussen, C., Baker, W.J., Harley, M. and Lewis, C. (2008) Genera Palmarum. The Evolution and Classification of Palms. Kew Publishing, Royal Botanical Gardens, UK, 732.

[3] Verheye, W. (2010) Growth and Production of Oil Palm. In: Verheye, W., Ed., Land Use, Land Cover and Soil Sciences, Encyclopedia of Life Support Systems (EOLSS), UNESCO-EOLSS Publishers, Oxford.

[4] Jacquin, N.J. (1763) Nicolai Josephi Jacquin Selectarum Stirpium Americanarum Historia: In: Qua Ad Linnæanum Systema Determinatæ Descriptæque Sistuntur Plantæ Illæ, Quas in Insulis Martinica, Jamaica, Domingo, Alliisque, et in Vicinæ Continentis Parte, Vindobona: Ex Officina Krausiana, 1727-1817.

[5] Montufar, R., Louise, C. and Tranbarger, T.J. (2018) Elaeis oleifera (Kunth) Cortes: A Neglected Palm from the Ecuadorian Amazon. Revista Ecuatoriana de Medicina $y$ Ciencias Biologicas, 39, 11-18.

[6] Leiben, R.W. (1973) Medical Anthropology. In: Horigman, J.J., Ed., Handbook of Social and Cultural Anthropology, McNally College Publishing Company, Chicago, 87-92.

[7] Krentz, A.J. and Bailey, C.J. (2005) Oral Antidiabetic Agents: Current Role in Type 2 Diabetes Mellitus. Drugs, 65, 385-411. https://doi.org/10.2165/00003495-200565030-00005 
[8] Farnsworth, N.R., Akerele, O., Bingel, A.S., Soejarto, D.D. and Guo, Z.G. (1985) Medicinal Plants in Therapy. Bulletin of the World Health Organization, 63, 965-981.

[9] Irvine, F.R. (1961) Woody Plants of Ghana: With Special Reference to Their Uses. Oxford University Press, London.

[10] Maley, J. and Chepstow-Lusty, A. (2001) Elaeis guineensis Jacq. (Oil Palm) Fluctuations in Central Africa during the Late Holocene: Climate or Human Driving Forces for This Pioneering Species? Vegetation History and Archaeobotany, 10, 117-120. https://doi.org/10.1007/PL00006920

[11] Logan, A.L. and D’Andrea, A.C. (2012) Oil Palm, Arboriculture, and Changing Subsistence Practices during Kintampo Times (3600-3200 BP, Ghana). Quaternary International, 249, 63-71. https://doi.org/10.1016/j.quaint.2010.12.004

[12] D’Andrea, A.C., Kahlleber, S., Logan, A.L. and Watson, D.J. (2007) Early Domesticated Cowpea (Vigna unguiculata) from Central Ghana. Antiquity, 81, 686-698. https://doi.org/10.1017/S0003598X00095661

[13] Kenneth, F.K. and Ornelas, K.C. (2000) The Cambridge World History of Food. Cambridge University Press, Cambridge, 1120.

[14] Smith, N. (2015) Elaeis oleifera 32. In: Smith, N., Ed., Palms and People in the Amazon, Geobotany Studies, Springer International Publishing, Switzerland, 225-234.

[15] Irvin, T. (1985) Wound Healing. Archives of Emergency Medicine, 2, 3-10. https://doi.org/10.1136/emj.2.1.3

[16] Opute, F.I. (1975) Lipid and Sterol Composition of the Pollen of the West African Oil Palm Elaeis guineensis. Phytochemistry, 14, 1023-1026. https://doi.org/10.1016/0031-9422(75)85180-6

[17] Chong, K.H., Zuraini, Z., Sasidharan, S., Devi, P.V.K., Latha, L.Y. and Ramanathan, S. (2008) Antimicrobial Activity of Elaeis guineensis Leaf. Pharmacologyonline, 3, 379-386.

[18] Coe, F.G. (1997) Ethnobotany of the Miskitu of Eastern Nicaragua. Journal of Ethnobiology, 17, 171-214.

[19] Johnson, D.V. (2010) Non-Wood Forest Products: 10/Rev.1, Tropical Palms, 2010 Version. Food and Agriculture Organization of the United Nations, Rome, 242.

[20] Obahiagbon, F.I. (2012) A Review: Aspects of the African Oil Palm (Elaeis guineensis Jacq.). American Journal of Biochemistry and Molecular Biology, 2, 1-14.

[21] Aiyeloja, A.A. and Bello, O.A. (2006) Ethnobotanical Potentials of Common Herbs in Nigeria: A Case Study of Enugu State. Educational Research and Review, 1, 16-22.

[22] Mathaba, S. (2017) Assessing the Advantages of Cultivation and Consumption of Traditional Vegetables for Public Health in South Africa. PULA: Botswana Journal of African Studies, 31, 140-150.

[23] Weston, G.D. (1994) Crop Physiology (Biotechnology by Open Learning). Butterworth-Heinemann, Oxford, 158.

[24] Darrell, P. (1990) Plants and Culture: Ethnobotany and Education. Royal Botanic Garden, 20A Inverleith Row, Edinburgh EH3 5LR, Scotland, 258.

[25] Khalid, H., Abdalla, W.E., Abdelgadir, H., Opatz, T. and Efferth, T. (2012) Gems from Traditional North-African Medicine: Medicinal and Aromatic Plants from Sudan. Natural Products and Bioprospecting, 2, 92-103.

https://doi.org/10.1007/s13659-012-0015-2 
[26] Adjanohoun, E.J., Ahyi, A.M.R., AkéAssi, L., Baniakina, J., Chibon, P., Cusset, G., Doulou, V., Enzanza, A., Eyme, J., Goudote, E., Keita, A., Mbemba, C., Mollet, J., Moutsambote, J.M., Mpati, J. and Sita, P. (1988) Contribution Aux Etudes Ethnobotaniqueset Floristiques en Republique Populaire du Congo. Medecine Traditionelleet Pharmacopée. Agence de Coopération Culturelleet Technique, Paris.

[27] Quenum, J.C. (1999) Education traditionnelle Au benin, La place du sacrédans Les rites initiatiques. International Review of Education, 45, 281-303. https://doi.org/10.1023/A:1003846727708

[28] Corrigan, B.M., Van Wyk, B.E., Geldenhuys, C.J. and Jardine, J.M. (2011) Ethnobotanical plantuses in the Kwa-Nibela Peninsula, St Lucia, South Africa. South African Journal of Botany, 77, 346-359. https://doi.org/10.1016/j.sajb.2010.09.017

[29] Cox, P.A. and Balick, M.J. (1994) The Ethnobotanical Approach to Drug Discovery. Scientific American, 60-65.

[30] Gruca, M., Camara-Leret, R., MacIa, M.J. and Balslev, H. (2014) New Categories for Traditional Medicine in the Economic Botany Data Collection Standard. Journal of Ethnopharmacology, 155, 1388-1392. https://doi.org/10.1016/j.jep.2014.06.047

[31] Gary, S. (1930) Turtle Island, Ethnobotany. US Poet, Essayist and Translator.

[32] Gruca, M., van Andel, T.R. and Balslev, H. (2014) Ritual Uses of Palms in Traditional Medicine in Sub-Saharan Africa: A Review. Journal of Ethnobiology and Ethnomedicine, 10, 60. https://doi.org/10.1186/1746-4269-10-60

[33] Owoyele, B.V. and Owolabi, G.O. (2014) Traditional Oil Palm (Elaeis guineensis Jacq.) and Its Medicinal Uses: A Review. TANG Humanitas Medicine, 4, e16.

[34] Mohamed, S. (2014) Oil Palm Leaf: A New Functional Food Ingredient for Health and Disease Prevention. Journal of Food Processing and Technology, 5, 300. https://doi.org/10.4172/2157-7110.1000300

[35] Betti, J.L. (2001) Usages traditionnels et vulnérabilité des plantes médicinales dans la réserve de biosphère du Djaet dans les marchés de Yaoundé, cameroun. ThèseDoctorat, UniversitéLibre de Bruxelles, 432.

[36] Ajibesin, K.K., Ekpo, B.A., Bala, D.N., Essien, E.E. and Adesanya, S.A. (2008) Ethnobotanical Survey of Akwa Ibom State of Nigeria. Journal of Ethnopharmacology, 115, 387-408. https://doi.org/10.1016/j.jep.2007.10.021

[37] Duke, J.A. and Wain, K.K. (1981) Medicinal Plants of the World. Computer Index with More than 85,000 Entries, 3 Vols.

[38] Duke, J. (1983) Handbook of Energy Crops. University of Purdue, Center for New Crops and Plant Products, 1-5.

[39] Anwana, E.D., Nyah, G. and Mbong, E.O. (2015) Valuation of Social Relevance of Plants amongst the Annangs in South-South Nigeria. European Journal of Biomedical and Pharmaceutical Sciences, 2, 328-337.

[40] Yin, N.G.S., Abdullah, S. and Phin, C.K. (2013) Phytochemical Constituents from Leaves of Elaeis guineensis and Their Antioxidant and Antimicrobial Activities. International Journal of Pharmacy and Pharmaceutical Sciences, 5, 137-140.

[41] Mann, A., Gbate, M. and Umar, A.N. (2003) Medicinal and Economic Plants of Nupeland. Jube-Evans Books and Publications, Bida, 33-121.

[42] Wang, L., Waltenberger, B., Pferschy-Wenzigm, E.M., Blunderm, M., Lium, X., Malainer, C., Blazevic, T., Schwaiger, S., Rollinger, J.M., Heiss, E.H., Schuster, D., Kopp, B., Bauer, R., Stuppner, H., Dirsch, V.M. and Atanasov, A.G. (2014) Natural Product Agonists of Peroxisome Proliferator-Activated Receptor Gamma (PPAR $\gamma$ ): A Review. Biochemical Pharmacology, 92, 73-89. 
https://doi.org/10.1016/j.bcp.2014.07.018

[43] Betti, J.L. (2004) An Ethnobotanical Study of Medicinal Plants among the Baka Pygmies in the Dja Biosphere Reserve, Cameroon. African Study Monographs, 25, $1-27$.

[44] Olusola, J.A. and Oyeleke, O.O. (2015) Survey and Documentation of Medicinal Plants in Wildlife Park of Federal University of Technology, Akure, Nigeria. International Journal of Life Sciences Research, 3, 238-246.

[45] Focho, D.A., Newu, M.C., Anjah, M.G., Nwana, F.A. and Fonge, B.A. (2009) Ethnobotanical Survey of Trees in Fundong, Northwest Region, Cameroon. Journal of Ethnobiology and Ethnomedicine, 5, 17. https://doi.org/10.1186/1746-4269-5-17

[46] Asase, A., Akwetey, G.A. and Achel, D.G. (2010) Ethnopharmacological Use of Herbal Remedies for the Treatment of Malaria in the Dang Me West District of Ghana. Journal of Ethnopharmacology, 129, 367-376. https://doi.org/10.1016/j.jep.2010.04.001

[47] Das, N., Islam, Md.E., Jahan, N., Islam, M.S., Khan, A., Islam, M.R. and Parvin, M.S. (2014) Antioxidant Activities of Ethanol Extracts and Fractions of Crescentia cujete Leaves and Stem Bark and the Involvement of Phenolic Compounds. BMC Complementary and Alternative Medicine, 14, 45. https://doi.org/10.1186/1472-6882-14-45

[48] Weremfo, A., Adinortey, M.B. and Pappoe, A.N.M. (2011) Wound Healing Potential of Musa paradisiaca L. (Musaceae) Stem Juice Extract Formulated into An Ointment. Research Journal of Pharmacology and Pharmacodynamics, 3, 294-296.

[49] Tchacondo, T., Karou, S.D., Agban, A., Bako, M., Batawila, K., Bawa, M.L., Gbeassor, M. and de Souza, C. (2012) Medicinal Plants Use in Central Togo (Africa) with an Emphasis on the Timing. Pharmacognosy Research, 4, 92-103. https://doi.org/10.4103/0974-8490.94724

[50] Idu, M., Erhabor, J.O. and Ovuakporie-Uvo, O. (2014) Ethnomedicinal Plants Used by the Idoma People-Benue State, Nigeria. American Journal of Ethnomedicine, 1 , 72-88.

[51] Soladoye, M.O., Amusa, N.A., Raji-Esan, S.O., Chukwuma, E.C. and Taiwo, A.A. (2010) Ethnobotanical Survey of Anti-Cancer Plants in Ogun State, Nigeria. Annals of Biological Research, 1, 261-273.

[52] Kayode, J., Akinyele, O. and Ayeni, M.J. (2017) Ethnobotany of Ecological-Based Tourist Centres in the Western Zone of Ekiti State, Nigeria. Ecology and Evolutionary Biology, 2, 78-86. https://doi.org/10.11648/j.eeb.20170205.12

[53] Burkill, H.M. (1997) The Useful Plants of West Tropical Africa. 2nd Edition, Volume 4 (Families M-R), Royal Botanical Gardens, Kew.

[54] Ajibesin, K.K., Bala, D.N. and Umoh, U.F. (2011) The Use of Medicinal Plants to Treat Sexually Transmitted Diseases in Nigeria: Ethnomedicinal Survey of Niger Delta Region. International Journal of Green Pharmacy, 5, 181-191. https://doi.org/10.4103/0973-8258.91224

[55] Gill, L. (1992) Ethnomedical Uses of Plants in Nigeria. UNIBEN Press, Benin City, 275.

[56] Sasidharan, S., Logeswaran, S. and Latha, L.Y. (2011) Wound Healing of Elaeis guineensis leaf Extract Ointment. International Journal of Molecular Sciences, 13, 336-347. https://doi.org/10.3390/ijms13010336

[57] Diame, G.L.A. (2010) Ethnobotany and Ecological Studies of Plants Used for Reproductive Health: A Case Study at Bia Biosphere Reserve. The Western Region of 
Ghana, The Division of Ecological Sciences UNESCO (MAB) Young Scientist Research Award Scheme, Paris, Cedex 15, France, UNESCO, Accra Office.

[58] Sasidharan, S., Sharmini, R., Vijayarathna, S., Latha, L.Y., Vijenthi, R., Amala, R. and Amutha, S. (2009) Antioxidant and Hepatoprotective Activity of Methanolic Extracts of Elaeis guineensis Jacq Leaf. Pharmacologyonline, 3, 84-90.

[59] Ibraheem, Z.O., Sattar, M.A., Abdullah, N.A., Hassan, R. and Johns, E.J. (2012) Toxicity, Phytochemical Content and Antioxidant Activity Assessment Studies for Standardized Ethanolic Fraction of Palm Oil Leaf Extract. Pharmacognosy Communications, 2, 21-30.

[60] Ainslie, J.R. (1937) A List of Plants Used in Native Medicine in Nigeria. Imperial Forestry Institute, University of Oxford, Institute Paper No. 7.

[61] Walker, A.R. (1953) Usages pharmaceutiques des plantesspontanées du Gabon, 1. Bulletin Institutd Études Centrafricaines, Nouvelle Série, 6, 275-321.

[62] Adjanohoun, E.J., Adjakidje, V., Ahyi, M.R.A., AkeAssi, L., Akoegninou, A., d'Almeida, J., Apovo, F., Boukef, K., Chadare, M., Cusset, G., Dramane, K., Eyme, J., Gassita, J.N., Gbaguidi, N., Goudote, E., Guinko, S., Houngnon, P., Lo, I., Keita, A., Kiniffo, H.V., Kone-Bamba, D., MusampaNseyya, A., Saadou, M., Sodogandji, T., De Souza, S., Tchabi, A., ZinsouDossa, C. and Zohoun, T. (1989) Contribution aux etudes ethnobotaniques et floristiques en Republique Populaire du Benin. ACCT, Paris, 895.

[63] El-Hilaly, J., Hmammouchi, M. and Lyoussi, B. (2003) Ethnobotanical Studies and Economic Evaluation of Medicinal Plants in Taounate Province (Northern Morocco). Journal of Ethnopharmacology, 86, 149-158. https://doi.org/10.1016/S0378-8741(03)00012-6

[64] Idu, M. and Onyibe, H.I. (2007) Medicinal Plants of Edo State, Nigeria. Research Journal of Medicinal Plants, 1, 32-41. https://doi.org/10.3923/rjmp.2007.32.41

[65] Agyare, C., Asase, A., Lechtenberg, M., Niehues, M., Deters, A. and Hensel, A. (2009) An Ethnopharmacological Survey and In Vitro Confirmation of Ethnopharmacological Use of Medicinal Plants Used for Wound Healing in Bosomtwi-Atwima-Kwanwomaarea, Ghana. Journal of Ethnopharmacology, 125, 393-403. https://doi.org/10.1016/j.jep.2009.07.024

[66] Mojisola, C.O.C., Oladele, A.T. and Elufioye, T.O. (2012) Ethnobotanical Survey of Plants Used as Memory Enhancer and Antiaging in Ondo State, Nigeria. International Journal of Pharmaceutics, 2, 26-32.

[67] Rajavel, V., Sattar, M.Z.A., Abdulla, M.A., Kassim, N.M. and Abdullah, N.A. (2012) Chronic Administration of Oil Palm (Elaeis guineensis) Leaves Extract Attenuates Hyperglycaemic-Induced Oxidative Stress and Improves Renal Histopathology and Function in Experimental Diabetes. Evidence-Based Complementary and Alternative Medicine, 195367.

[68] Idu, M., Oghale, O.U. and Sarah, I.M.O. (2017) Indigenous Plants Used by the Otuo Tribe of Owan East Local Government Area, Edo State, Nigeria. Journal of Medicinal Plants for Economic Development, 1, a10. https://doi.org/10.4102/jomped.v1i1.10

[69] Jaiswal, S., Singh, S.V., Singh, B. and Sinha, H. (2004) Plants Used for Tissue Healing of Animals. Natural Product Radiance, 3, 284-292.

[70] Chopda, M.Z. and Mahajan, R.T. (2009) Wound Healing Plants of Jalgaon District of Maharashtra State, India. Ethnobotany Leaflets, 13, 1-32.

[71] Betti, J.L., Iponda, D.M., Yongo, O.G., Mbomio, D.O., Yobo, C.M., Ngoye, A. and Issembe, Y. (2013) Ethnobotanical Study of Medicinal Plants of the Ipas- 
sa-Makokou Biosphere Reserve, Gabon: Plants Used for Treating Malaria. Journal of Medicinal Plants Research, 7, 2300-2318. https://doi.org/10.5897/JMPR12.1211

[72] Barku, V.Y.A. (2018) Wound Healing: Contributions from Medicinal Plants and Their Phytoconstituents. Annual Research and Review in Biology, 26, 1-14. https://doi.org/10.9734/ARRB/2018/41301

[73] Innocent, E., Gikonyo, N.K. and Nkunya, M.H.H. (2008) Repellency Property of Long Chainaliphatic Methyl Ketones against Anopheles gambiaes. Tanzania Journal of Health Research, 10, 50-54. https://doi.org/10.4314/thrb.v10i1.14342

[74] Youmsi, R.D.F., Fokou, P.V.T., Menkem, E.Z., Bakarnga-Via, I., Keumoe, R., Nana, V. and Boyom, F.F. (2017) Ethnobotanical Survey of Medicinal Plants Used as Insects Repellents in Six Malaria Endemic Localities of Cameroon. Journal of Ethnobiology and Ethnomedicine, 13, 33. https://doi.org/10.1186/s13002-017-0155-x

[75] Tulley, P. (1964) How to Tap Raphia Palm Wine. The Nigerian Field, 55, 59-64.

[76] Ukhun, M.E., Okolie, N.P. and Oyerinde, A.O. (2005) Some Mineral Profiles of Fresh and Bottled Palm Wine: A Comparative Study. African Journal of Biotechnology, 4, 829-832.

[77] Bassir, O. (1968) Some Nigerian Wines. West African Journal of Biology and Chemistry, 10, 42-45.

[78] Syahmi, A.R.M., Vijayarathna, S., Sasidharan, S., Latha, L.Y., Kwan, Y.P., Lau, Y.L., Shin, L.N. and Chen, Y. (2010) Acute Oral Toxicity and Brine Shrimp Lethality of Elaeis guineensis Jacq., (Oil Palm Leaf) Methanol Extract. Molecules, 15, 8111-8121. https://doi.org/10.3390/molecules15118111

[79] Obahiagbon, F.I., Oviasogie, P.O., Ukhun, M.E. and Oviawe, P.N. (2007) Comparative Studies of the Thiamine and Riboflavin Contents in the Sap of Raphia hookeri Palm by the Application of Fluorimetric Method and Arrhenius Equation. Trends in Applied Sciences Research, 2, 260-263. https://doi.org/10.3923/tasr.2007.260.263

[80] Sourabie, T.S. (2006) Enquêtes ethnobotanique set ethnopharmacognosiques dans la zone de la mare aux hippopotames de Bala. Rapport de mission du Projet MAB du 16 au 23 mars, 11.

[81] Fongod, A.G.N., Ngoh, L.M. and Veranso, M.C. (2014) Ethnobotany, Indigenous Knowledge and Unconscious Preservation of the Environment: An Evaluation of Indigenous Knowledge in South and Southwest Regions of Cameroon. International Journal of Biodiversity and Conservation, 6, 85-99. https://doi.org/10.5897/IJBC2013.0637

[82] Kadiri, M., Ojewumi, A.W., Abiola, T.O. and Hussain, M.A. (2014) Ethno-Botanical Survey of Plants Commonly Used for Ceremonial Activities among Yoruba Tribe of South West, Nigeria. Direct Research Journal of Health and Pharmacology, 2, 1-5.

[83] Adeogun, I.I., Fawibe, O.O., Ajiboye, A.A. and Agboola D.A. (2014) Ethnobotanical Survey of Medicinal Plants Used in the Treatment of Skin Diseases in Abeokuta South Local Government of Ogun State. Asian Journal of Pharmaceutical Technology and Innovation, 2, 1-14.

[84] Fred-Jaiyesimi, A., Ajibesin, K.K., Tolulope, O. and Gbemisola, O. (2015) Ethnobotanical Studies of Folklore Phytocosmetics of South West Nigeria. Pharmaceutical Biology, 53, 313-318. https://doi.org/10.3109/13880209.2014.918155

[85] Fasola, T.R. (2015) An Ethnobotanical Survey of Plants Used in the Management and Treatment of Female Reproductive Health Problems in Ibadan, Southwestern Nigeria. Journal of Biology, Agriculture and Healthcare, 3, 7-11. 
[86] Kamilindi, C. (1950) Les Plantes Médicinales Au Ruanda-Urundi Servir, 11, 99-100.

[87] Harley, G.W. (1970) Native African Medicine: With Special Reference to Its Practice in the Mano Tribe of Liberia. Frank Cass and Company Limited, London.

[88] Maclean, U. (1977) Magical Medicine: A Nigerian Case-Study. Penguin Books, London, New York.

[89] Akendengue, B. and Louis, A.M. (1994) Medicinal Plants Used by Masango People in Gabon. Journal of Ethnopharmacology, 41, 193-200. https://doi.org/10.1016/0378-8741(94)90032-9

[90] Henderson, J. and Osborne, D.J. (2000) The Oil Palm in All Our Lives: How This Came about. Endeavour, 24, 63-68. https://doi.org/10.1016/S0160-9327(00)01293-X

[91] Iwu, M.M. (2014) Handbook of African Medicinal Plants. 2nd Edition, CRC Press, 464. https://doi.org/10.1201/b16292

[92] Soladoye, M.O., Chukwuma, E.C., Sulaiman, O.M. and Feyisola, R.T. (2014) Ethnobotanical Survey of Plants Used in the Traditional Treatment of Female Infertility in Southwestern Nigeria. Ethnobotany Research and Applications, 12, 81-90.

[93] Arsic, I., Zugic, A., Antic, D.R., Zdunic, G., Dekanski, D., Markovic, G. and Tadic, V. (2010) Hypericum perforatum L. Hypericaceae/Guttiferae Sunflower, Olive and Palm Oil Extracts Attenuate Cold Restraint Stress-Induced Gastric Lesions. Molecules, 15, 6688-6698. https://doi.org/10.3390/molecules15106688

[94] Irvine, F.R. (1948) The Indigenous Food Plants of West African Peoples, Part 1. Journal of the New York Botanical Garden, 49, 225-236.

[95] Hartley, C.W.S. (1977) The Oil Palm. Longmans, London, 618.

[96] Zeven, A.C. (1972) The Oil Palm in West Africa. Economic Botany, 26, 274-279. https://doi.org/10.1007/BF02861041

[97] Kweifio-Okai, G. (1991) Anti-Inflammatory Activity of a Ghanaian Antiarthritic Herbal Preparation: I. Journal of Ethnopharmacology, 33, 263-267. https://doi.org/10.1016/0378-8741(91)90087-T

[98] Bakoume, C. (2006) Sustainable Development of Oil Palm in Africa: Small Holders' Sector. International Planters' Conference, Kuala Lumpur, 26-28 June 2006.

[99] Aniama, S.O., Usman, S.S. and Ayodele, S.M. (2016) Ethnobotanical Documentation of Some Plants among Igala People of Kogi State. The International Journal of Engineering and Science, 5, 33-42.

[100] Sowunmi, M.A. (2002) Environmental and Human Responses to Climatic Events in West and West Central Africa during the Late Holocene. In: Hassan, F.A., Ed., Droughts, Food, and Culture: Ecological Change and Food Security in Africa's Later Prehistory, Kluwer Academic, New York, 95-104. https://doi.org/10.1007/0-306-47547-2_7

[101] Hedrick, U.P. (1972) Sturtevant's Edible Plants of the World. Dover Publications, New York.

[102] Jones, D.L. (1995) Palms throughout the World. Smithsonian Institution Press, Washington DC.

[103] Schultes, R.E. (1990) Taxonomic, Nomenclatural and Ethnobotanic Notes on Elaeis. Elaeis, 2, 172-187.

[104] Dalziel, J.M. (1937) Flora of West Tropical Africa. Crown Agents for Overseas Government, 1-296.

[105] CABI (2005) Forestry Compendium. CABI, Wallingford.

[106] USDA-ARS (2008) Germplasm Resources Information Network (GRIN). National 
Germplasm Resources Laboratory, Beltsville, Maryland. https://npgsweb.ars-grin.gov/gringlobal/taxon/taxonomysearch.aspx

[107] FAO (2009) FAOSTAT Online Statistical Service. Food and Agriculture Organization of the United Nations, Rome. http://faostat.fao.org/

[108] Missouri Botanical Garden (2008) Tropicos Database. Missouri Botanical Garden, St Louis.

[109] PIER (2008) Pacific Islands Ecosystems at Risk. Institute of Pacific Islands Forestry.

[110] USDA-NRCS (2008) The PLANTS Database. National Plant Data Center, Baton Rouge.

[111] Borchsenius, F., Pedersen, H.B. and Balslev, H. (1998) Manual to the Palms of Ecuador. AAU Report 37. Department of Systematic Botany, University of Aarhus.

[112] Gruca, M., Blach-Overgaard, A. and Balslev, H. (2015) African Palm Ethno-Medicine. Journal of Ethnopharmacology, 165, 227-237.

https://doi.org/10.1016/j.jep.2015.02.050 